\title{
"Nous alone enters from outside" Aristotelian embryology and early Christian philosophy
}

Sophia Connell

In a work entitled On the Generation of Animals, Aristotle remarks that "intellect (nous) alone enters from outside (thurathen)". Interpretations of this passage as dualistic dominate the history of ideas and allow for a joining together of Platonic and Aristotelian doctrine on the soul. This, however, pulls against the well-known Aristotelian position that soul and body are intertwined and interdependent. The most influential interpretations thereby misrepresent Aristotle's view on soul and lack any real engagement with his embryology. This paper seeks to extract the account of intellect (nous) in Aristotelian embryology from this interpretative background and place it within the context of his mature biological thought. A clear account of the actual import of this statement in its relevant context is given before explaining how it has been misunderstood by various interpretative traditions. The paper finishes by touching on how early commentary by Christian writers, freed as it was from the imperative to synthesise Greek philosophy, differed from those that came after. While realising that Aristotle's position would not aid them in their explanations of the soul's survival after death, their engagement with Aristotle's science allowed for other aspects of theology concerning the fittingness of soul to body.

In a work entitled On the Generation of Animals, Aristotle writes the following:

(A) Intellect (nous) alone remains to enter from outside and it is the one [soul part] that is divine. ${ }^{1}$

This truncated and obscure text, the most famous from the entire work, suggests a substance dualism that supports Abrahamic religious doctrine. This statement along with two other related passages from the work have led to a series of misunderstandings which come in part from the separation of such passages from their context in Aristotelian biological thought and in part from a desire to combine Platonic and Aristotelian

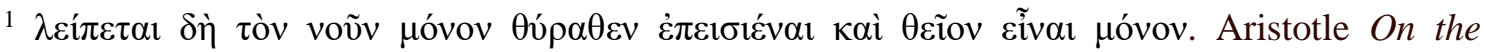
Generation of Animals (GA) 2.3.736b27-28. Aristotelis De Generatione Animalium, ed. H. J. Drossaart Lulofs, (Oxford: Clarendon Press, 1965), 61. All line numbers in Aristotle follow Aristotelis Opera ex Recensione Immanuelis Bekkeri Edidit Academia Regia Borussica Accedunt Fragmenta Scholia Index Aristotelicus, ed. I. Bekker, 5 vols. (Berlin: Georgium Reimerum, 18311836).
} 
doctrines. In contrast with these traditions, early Christian thinkers tended to realise the centrality of the body for Aristotle and so had a different viewpoint on these texts. While recognising that Aristotle should not be used to support substance dualism and personal immorality, they allowed for Aristotelian embodied psychology to illuminate other aspects of Christian theology.

This paper will begin (section I) with a thorough Aristotelian analysis of the passages on 'nous thurathen' in the context of Aristotle's biology, explaining why they cannot fit Aristotle's view on the separability and divinity of 'intellect' (nous). Section (II) gives an account of why he raised the question in the first place and its probable import. The third section (III) will set out four main misrepresentations of Aristotle on intellect in his embryology and trace their history of misinterpretations, with the exception of certain early Christian thinkers, who do not wish to adopt Aristotle as part of their own doctrine on the soul. Section (IV) will consider what role, if any, Aristotle's view of the importance of the body in the development and existence of human beings played in early Christian theology.

I - Analysis of passages from Aristotle's On the Generation of Animals in their embryological and psychological context

The same portion of On the Generation of Animals which provide us with passage (A) also contains the following oft-quoted passage:

(B) For in all cases, in the seed, there exists that which makes the seed fertile, the so-called hot. This is not fire or a power of that sort, but is pneuma which is enveloped in the seed and in the foam, I mean the nature in the pneuma, being analogous [to the nature] of the element of the stars. ${ }^{2}$

Another passage which will be important is the one that further mentions the special status of intellect (nous) as "separable".

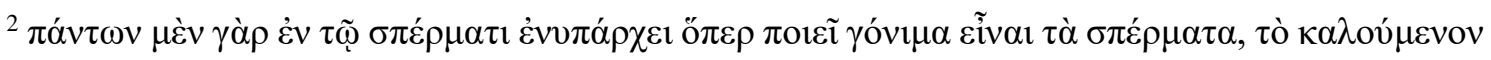

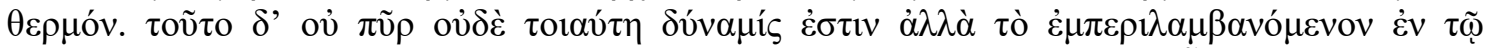

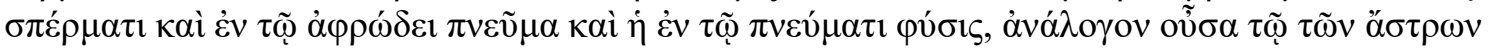

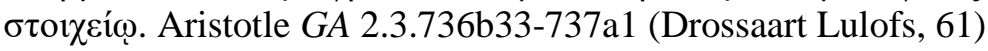


(C) The principle of soul which departs with the body of the semen, is on the one hand separable (in those which enclose something divine, this is the so-called intellect [nous]), on the other hand inseparable. The body of the semen dissolves and evaporates, having a fluid and watery nature. ${ }^{3}$

Passages (A)-(C) occur in Book 2 of the treatise in the context of Aristotle's declaring a series of puzzles (aporiai) for his theory of generation. In Book I Aristotle argues that rival theories which focus on the mixing of materials from parents cannot explain the organised products of generation; instead there must be a power which actively constructs the living body (GA 1.23.723b25-30). The male principle is this efficient cause - the

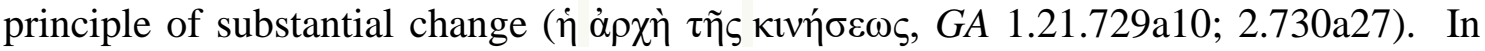
Book 2 Aristotle asks: is the fashioning power something that enters from outside and forms the body and then disappears (GA 2.1.734a5-9)? Or does it become a part of the animal (734a13)? How does agency get from the male animal to the offspring and continue to direct development when no longer in contact (733b33-734a3)? The puzzles Aristotle articulates in GA 2.1-3 can be broken down roughly into five as follows. ${ }^{4}$

a. "How does any plant come to be formed out of seeds or any animal in the same way?" (GA 1.1.733b23-5)

i. "Either something external makes them,

ii. or else something present in the semen...". (733b33-734a2)

b. Are all the parts formed at once or one after the other? (734a17)

c. What is male semen composed of and what are its evident properties? (GA 2.2)

d. Does the male semen become any part of the animal in the end?

e. Is "soul... present in the seed (sperma) and fetation (kuêma) to begin with and where [does] it come[s] from"? (GA 2.3.736a29-32)

Our passages emerge from puzzles (a) and (e). The male and female contributions are active and passive potentials to effect substantial generation (GA 1.21.729a28-31; Ph. 3.3.202a13-19). For nutritive and sentient capacities, Aristotle resists the idea of soul entering in from outside, which was a view held by almost all other ancient theorists. The

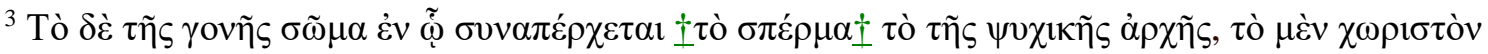

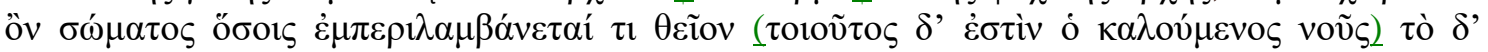

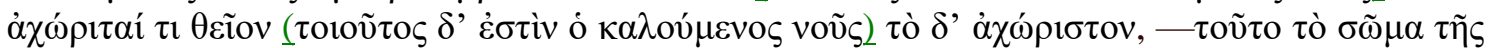

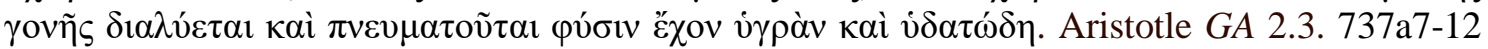
(Drossaart Lulofs, 61).

${ }^{4}$ The problems posed are not actually resolved in GA 2.1-3. The main question of how soul gets from father to offspring may not be fully accounted for until GA 2.6. See especially A. Gotthelf, "Teleology and Embryogenesis in Aristotle's Generation of Animals II.6." in Teleology, First Principles, and Scientific Method in Aristotle's Biology (Oxford: Oxford University Press), 90116. For a fuller account of these puzzles see S. M. Connell, "How Does a Living Animal Come to be from Semen? The Puzzles of Aristotle's Generation of Animals II 1-3," Life and the Science of Life in Aristotle and Aristotelianism, ed. in D. Lefebvre (Leiden: Brill, forthcoming).
} 
new animal, with all its eventual capacities, is present potentially in the activated materials and so does not need to enter from outside. But nous would seem to present a special case. The gradual development of the bodily parts coincides with the actualisation of nutritive and sentient capacities (GA 2.1.734b22-4), even when the latter may be mainly dormant. But how can we tell when the embryo has (potential, dormant) intellectual soul as the activity of thinking is not the actualisation of any part of the body (GA 1.1.736b28-29)? As it is not directly connected to any developing part of the body, this means it is possible for it to enter "from outside". If nous can enter "from outside" it needs to be able to be (at least at times) separable from the body and the other soul capacities.

In what sense, if any, is it 'separable' from the body and the rest of the soul?

There are at least three different ways in which Aristotle's soul parts, nutrigeneration, sentient and intellectual, could be separable: taxonomically, conceptually and spatially (DA 2.2.413b11-16). ${ }^{5}$ Taxonomically means that there are some entities that have that part without the others, conceptually means they can be defined without references to the other parts, and spatially means that the parts exist in different locations. All three soul capacities are conceptually distinct. Nutri-generative soul is also taxonomically separate when it occurs in plants (DA 2.2.413a31-3). Sentient soul is not taxonomically separable; it cannot exist without the nutri-generative soul (DA 2.4.415a23-26; 3.12.434a22-26). The nutri-generative and sentient souls are not spatially distinct, since they exist simultaneously and co-extensively in those that possess both. Aristotle makes this very clear when he discusses certain insects which remain alive when bisected,: 'the whole soul' is retained in both animals that result. ${ }^{6}$ This position can be

\footnotetext{
${ }^{5}$ Miller gives a four-fold distinction of senses of separable, adding ontological to this list. As I do not see how any part of soul could be ontologically separable, I will not include this sense here (F. D. Miller "Aristotle on the Separability of Mind", In C. Shields (ed.) Oxford Handbook of Aristotle (Oxford: Oxford University Press, 2012), 306-339 at 309). I follow the account of the soul capacities in K. Corcilius and P. Gorgorić, "Separability vs. Difference. Parts and Capacities of the Soul in Aristotle", Oxford Studies in Ancient Philosophy (2010): 81-119.

${ }^{6}$ Soul is an essential unity that unifies the body (DA 1.5.410b16f.; Cf. DA 1.1.405b25f.; 411a8, 411b19-23; On Youth and Old Age, Life and Death 2.468a23-468b16).
} 
contrasted with that of Plato who in the Timaeus locates the three parts of soul in three portions of the body: appetites in the belly, spirit in the chest and intellect in the head. ${ }^{7}$

The separability of nous remains obscure. Taxonomically, it exists alone in God (i.e. thought thinking itself) ${ }^{8}$; but does it also somehow exist as spatially separable in human beings, since it alone is not centred in the heart and its operations and is not any direct function of bodily parts? Aristotle begins De Anima with the thought that "it is likely that all affections ( $\pi \alpha \dot{\theta} \theta \eta)$ of the soul are associated with the body" ( $D A$ 1.1.403a1718). A certain type of thinking or reasoning is an unusual case. Nous is parallel to sentient soul insofar as its function is to apprehend intellectual objects (sentient soul apprehends sensory objects) (DA 3.4.429a16-18). Sensory soul has the bodily sense organs which must be actualised and physically affected in order for sensation to occur. Nous, in contrast, does not depend on the body directly in this manner (DA 2.1.413a5-6; 3.4.429a26-27; GA 2.1.736b28-29). Aristotle mentions this fact in an explanatory (gar) clause directly after saying that nous enters from outside in Passage (A).

Nous alone remains to enter from outside and it is the one [soul part] that is divine. For its actualisation has nothing in common with the actualisation of the body. ${ }^{9}$

That nous does not have a specific bodily organ does not guarantee spatial separability; the common sense and imagination, for example, also do not have bodily organs exclusively for their exercise but are nonetheless dependent on the body. ${ }^{10}$ Furthermore, Aristotle thinks of human intellect as, for the most part, intertwined with and dependent on the other soul capacities which are tied to the body. In embryological context, the heart (or its analogue) as the first location of the soul principle, directs the development of the rest of the body (GA 2.6.742b35-743a4). For human beings, this will mean the sort of body that can one day think, including the structure of that body (the eventual upright

\footnotetext{
${ }^{7}$ Plato Timaeus 69d6-70a2. References to Plato follow pagination in: Platonis Opera Quae Extant Omnia, ed. H. Stephanus (Geneva, 1578).

${ }^{8}$ Aristotle, Metaphysics 12.7.

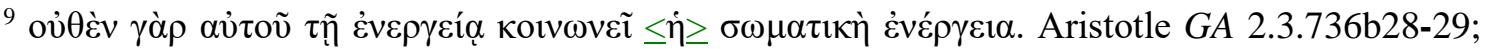
Drossaart Lulofs, 61.

${ }^{10}$ S. M. Connell "Thinking Bodies: Aristotle on the Biological Aspects of Human Cognition", in Encounters with Aristotle's Philosophy of Mind, ed. P. Gregorić and J. L. Fink (London: Routledge, 2021, 223-248 at 230. Charlton makes this point very clear, using the following example: "There is no organ for turning over in bed; nevertheless, there could not be a turnerover-in-bed without a body" (W. Charlton, "The Place of Mind in Nature", in Philosophical Issues in Aristotle's Biology, eds. A. Gotthelf and J. Lennox (Cambridge: Cambridge University Press, 1987), 408-23 at 417).
} 
orientation, On the Parts of Animals 4.10.686a27-32) and the texture of flesh and skin which allow for the most perceptive senses ( $D A$ 2.9.421a17-26). In a mature human, the nutritive soul continues to maintain parts such as these that support sublunary intelligence.

Furthermore, human intelligence is initially dependent on sentient soul. Thinking soul uses images derived from perception - the so-called phantasiai (DA 3.7.431a14-15; 431b2; 8, 432a3-10). ${ }^{11}$ Knowledge comes through the refinement of sensory information, building up experience ( $\left.\dot{\varepsilon} \mu \pi \varepsilon \imath p^{\prime} \alpha\right)$ in order to eventually form concepts. ${ }^{12}$ The first actuality of intellect is the gaining a body of knowledge which is then possessed - the second actuality is bringing that knowledge to bear or exercising it (DA 2.5.417a21-b2; Cf. GA 2.1.735a12-14). Actualisation at the second level is not directly dependent on perception (DA 2.5.417a21-28; 3.4.429b5-9) but is ultimately dependent on the first level which is. ${ }^{13}$ Thus do the texts support an Alexandrian understanding of nous entering from outside which is that at this second stage, the productive intellect is required to actualise the human passive intellect and this productive intellect is not in us but "above". ${ }^{14}$

Although all of that makes sense in Aristotelian terms, we are left with other passages that challenge that understanding. In the context of embryology, Passage (C) explicitly says that nous is separable:

The principle of soul which departs with ${ }^{15}$ the body of the semen, is on the one hand separable (in those which enclose something divine, this is the so-called nous), on the other hand inseparable. ${ }^{16}$

In his Clarendon commentary, Balme offers the following interpretation of this passage: "the sense is not in doubt: the semen brings with it both disembodied intellect and

${ }^{11}$ De Anima 3.7.432a7-8: "without having perceived anything one could neither learn anything

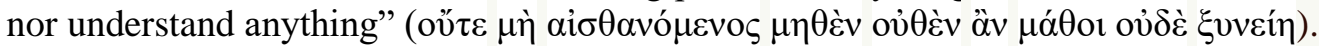

${ }^{12}$ Aristotle Posterior Analytics 2.19.

${ }^{13}$ For a more detailed account of the embodiment of intellect see Charlton "The Place of Mind in Nature" and Connell "Thinking Bodies". In contrast, Balme thinks that human thinking can exist independently of the body. For example, in his comments on PA 641a22 about whether nous is part of the study of nature, Balme cites GA 2.3 as evidence that nous "may exist independently of body" (Aristotle, Parts of Animals, 89).

${ }^{14}$ For Alexander of Aphrodisias, a person "[b]ecomes immortal when [she] thinks" (H. Davidson, Alfarabi, Avicenna, and Averroes on the Intellect (Oxford: Oxford University Press, 1992), 38).

${ }^{15}$ This is the meaning of $\sigma v v \alpha \pi \varepsilon \rho^{\prime} \chi 0 \mu \alpha \mathrm{l}$ at $G A 1.18 .725 \mathrm{~b} 14$.

${ }^{16}$ Aristotle GA 2.3.737a7-9. Drossaart Lulofs, 61. 
embodied nutritive and sensitive potentialities". ${ }^{17}$ The first problem for this interpretation is that if nous is disembodied, then it is hard to see how could it be carried in the pneuma in semen, a bodily mixture of elements ${ }^{18}$ As for nutritive and sentient soul, these are also not carried in pneuma in semen, since Aristotle is clear that they cannot exist in actuality, until they do so in potentiality (GA 2.3.736b14-15). Since the male semen evaporates and doesn't come to be any part of the offspring, no soul faculties are present potentially in the male contribution, in the passive sense of eventual development of these faculties. They are present potentially in that sense in the female contribution. ${ }^{19}$

Balme turns, as others do, to Passage (B) in speculating about how the male semen can 'physically' convey all three soul parts.

For in all cases, in the seed, there exists that which makes the seed fertile, the so-called hot. This is not fire or a power of that sort, but is pneuma which is enveloped in the seed and in the foam, I mean the nature in the pneuma that is analogous [to the nature] of the element of the stars. ${ }^{20}$

\section{Connecting Passages (C) and (B), Balme writes}

Now he goes on to say that the heat in pneuma has the special property of being able to convey soul, including intellect. He does not explain this in physical terms, but judging from 737a18-19 we may guess that he conceived it as conveying of movements superimposed upon the heat's own movements - perhaps as liquid conveys waves. ${ }^{21}$

\footnotetext{
${ }^{17}$ Aristotle, De Partibus Animalium I and De Generatione Animalium I (with passage from Book II. 1-3), translations and commentary by D. Balme (Oxford: Clarendon, 1992), 164-5.

${ }^{18}$ Others that think that nous is carried in male semen include Peck in Aristotle, Generation of Animals, trans. A. L. Peck (Cambridge, Mass.: Harvard University Press, 1942): 168-9 and Caston who claims that Aristotle's hylomorphic view of the generative contributions of male and female forces him to declare that nous comes "exclusively" from the male. Since the male contributes form and the female matter, and nous does not require the body, it has to come only from the male. There are various difficulties for this view, beginning with the fact that, for human beings, the maternal materials just as much as the male contribution of semen are poised to develop into the sort of body that is eventually able to think. In that sense, thinking is potentially present in the materials. Secondly, if nous comes from outside in any sense, it must come from outside the male semen and the embryo, "from outside" in the sense of not really "in" anything until thought happens. As such, it cannot be that it is "already present in the father's semen" (V. Caston, “Aristotle's Two Intellects: A Modest Proposal," Phronesis 94/3 (1999), 199-227 at 215).

${ }^{19}$ For a fuller argument along these lines see Connell "How Does a Living Animal Come to be from Semen?".

${ }^{20}$ Aristotle, GA 2.3.736b33-737a1.

${ }^{21}$ Balme in Aristotle Parts of Animals: 164-5.
} 
As Balme admits, Aristotle does not explain this in "physical terms". The question is elicited by interpreting coming "from outside" as the entry of something either immaterial carried in a material or as something material.

Certain interpreters think that these passages show that pneuma in male semen is a fifth sublunary element with special vital powers. ${ }^{22}$ Some even posit that this means a part of the most divine matter from the upper world is contained in male semen. ${ }^{23}$ The latter view is neither expressed nor implied by the passage. While the former view is less far-fetched, it unnecessarily materialises Aristotle's account of generation. Certainly as a tool the pneuma in semen is up to something interesting but its function cannot be reduced to what is composed of.

A brief analysis of Passage (B) will prove useful. The passage draws a comparison, specifically, an analogy. ${ }^{24}$ Analogies compare items or processes that are similar in certain ways, although they differ in others. Aristotelian analogies often focus on functional similarity. The passage does not say that semen contains aither but refers to aither as a useful comparison to a tool in the semen. Aither is an element which differs from the four elements below the moon, earth, air, fire and water because it moves only in circles, thus facilitating the eternal movement of the heavens (De Caelo 1.3). There is no implication that pneuma is a sublunary fifth element: the two are compared because of the similarities in the functions that they facilitate and not because they are both elements that differ from the other four. Indeed, pneuma is not another element, but rather a balanced mixture of the usual elemental powers. ${ }^{25}$

${ }^{22}$ One line of interpretation is that pneuma is a vehicle of "divine force" which "has its metaphysical origins in the transcendent divine intellect" (A. P. Bos, Aristotle on God's LifeGenerating Power and on Pneuma and its Vehicle (Albany, NY: State University of New York Press, 2018), 139). Although the evidence for this in Aristotle's biology is not strong, the goal of finding congruity between the traditional Aristotle corpus and less well known works such as the Eudemus (fragmentary) and On the Cosmos (of contested authenticity) is an interesting one.

${ }^{23}$ e.g. F. Nuyens, L'Évolution de la Psychologie d'Aristote (Louvain: Institute Supérier de Philosophie, 1948), A. Preus, Science and Philosophy in Aristotle's Biological Works (New York: Hildesheim, 1975), 85, J. Rist, The Mind of Aristotle: A Study in Philosophical Growth (Toronto: University of Toronto Press, 1989), C. D. C. Reeve, Substantial Knowledge: Aristotle's Metaphysics (Indianapolis, ID: Hackett, 2000), 48, 59.

${ }^{24}$ For a fuller account of this passage see S. M. Connell, Aristotle on Female Animals: A Study of the Generation of Animals (Cambridge: Cambridge University Press, 2016), 215-220.

${ }^{25}$ See D. Quarantotto, "Perishable and Imperishable Lives: Aristotle's Analogy with the Heavenly Element in GA II 3.736b29-737a5", in Life and the Science of Life in Aristotle and Aristotelianism, ed. in D. Lefebvre (Leiden: Brill, forthcoming). 
The passage doesn't say that pneuma is analogous to aither but rather that the 'nature' ( $\varphi v ́ \sigma ı \varsigma)$ of the heat which is enclosed in semen and foam is analogous to the 'nature' of the element of the stars. The broader discussion seeks to distinguish the heat in animal bodies from fire, an external element. Inanimate heat, such as external fire, is not under the control of soul, and so, as with all elements, does not have a limit. ${ }^{26}$ The passage continues thus:

This is the reason why fire generates no animal and no animal is put together in firey stuff, whether it liquid or solid. But the heat of the sun and that of animal, not only through seed, but also if there is any other natural residue, likewise this [residue] would possess a principle of life too. Therefore, it is clear from these things that the heat in animals is not fire and does not have its principle by fire. ${ }^{27}$

In the background is the Aristotelian argument against various Presocratic philosophers who endeavour to explain generation or other biological processes in terms of the mixing of elemental powers without reference to ends (e.g. De Incessu Animalium 2, PA 1.1). The way in which the nature of the heat in pneuma corresponds to the nature of aither is as follows. The nature of aither is to facilitate the continuous and never changing cyclical motion of the heavens. Aither is an instrument for the achievement of eternal circular motion, since the other elements move only rectilinearly. Heat in animals specifically associated the nutri-generative functioning is instrumental to the ends of that soul capacity - self-maintenance and generation. The nutri-generative soul ensures generation of another living being the same in kind to the parents. This is the only way that perishable living beings can participate in eternal existence (GA II.1, 731b31-35, de Anima II.4, 415a27-415b1). The nature of the two is analogous because these roles are both ultimately directed towards the type of eternal existence that is open to the substance in question.

\footnotetext{
${ }^{26}$ Alexander of Aphrodisias understood the difference between vital heat and external fire in this manner: "That which feeds itself...orders, provides a guided way and has a certain limit, which is something that is proper to soul and not to fire" (On Aristotle's De Anima 35.6-8). Alexander Aphrodisiensis, De Anima Libri Mantissa, with Introduction and Commentary by R. W. Sharples (Berlin: De Gruyter, 2008).

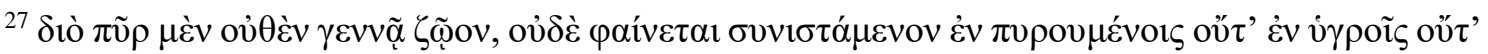

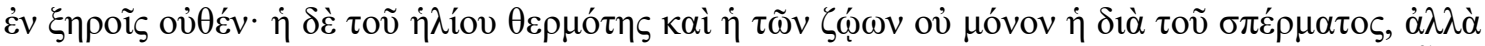

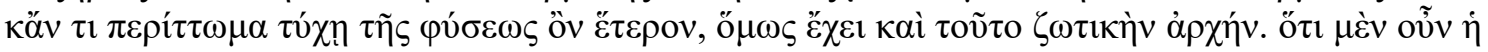

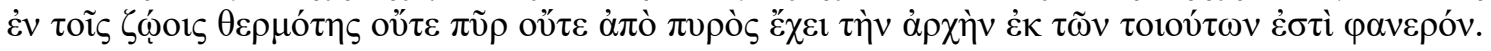
Aristotle, GA 2.3.737a1-7
} 
Some see the remarks about separability in Passage (C) as an interpolation; the text shows signs of corruption and the bracketed thought is incomplete. ${ }^{28}$ However, such swiftly expressed ideas are not uncommon in Aristotle. If the gist is that the principle of soul is on the one hand separable and the other inseparable, then this must mean that the soul that is set up by the male animal's active role in generation is inseparable from matter and the body in all animals that do not have nous. In the case of human beings, this principle of soul must also allow for the eventual separability conditions. The male originates a process that culminates in a new animal thinking. ${ }^{29}$ The mature soul of a human has aspects that are separable (in full theoretical reasoning mode) and aspects with aren't separable. The form human requires this; the male is human and his nutrigenerative soul will need to start another the same in form, with these two aspects of soul. $^{30}$

Although Balme is not seduced by the most far-fetching readings of these passages, he does not seem to realise that Aristotle is not concerned in terms of his own theory about how soul is conveyed in a physical sense to the embryo. Which makes us wonder why Aristotle gives us that impression in Passage (A).

\section{II - The meaning of "from outside"}

According to Aristotelian embryology, once the heart is established, it takes over the growth and development of the new animal, sending out blood vessels which form a network on which to build the other body parts (GA 2.6.742b35-743a2). The gradual

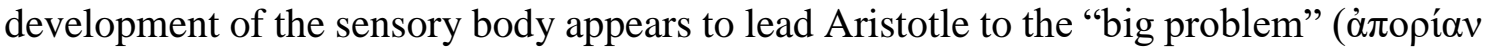
$\pi \lambda \varepsilon i ́ \sigma \tau \eta v)$ of "when, and in what way, and from where ( $\pi$ ó $\theta \varepsilon v$ ), do those that have a share in this principle [i.e. nous] takes their share?" (GA 2.3.736b5-6). The notorious comment in Passage (A) suggests that the principle of thinking comes "from outside" ( $\theta u ́ \rho \alpha \theta \varepsilon v)$.

\footnotetext{
${ }^{28}$ See especially Charlton who says the passage is "incurably corrupt" and that "it leaves the final sentence hanging in the air; Aristotle does not say definitely whether or not nous does come in from outside, but passes [on]...to a completely separate line of thought" (Charlton, "The Place of Mind in Nature": 414, 416).

29 "If we could press Aristotle, he might say that nous does differ from other kinds of soul in coming in from outside, but not in the way 736b15-29 suggests. Actual nous arises only when, as we grow up, we taken in forms of things without their matter, as stated in de An. iii.4' (Charlton "The Place of Mind in Nature", 416).

30 "736b29-737a7 allows the intellective soul just as much as the perceptive to come to be present in the embryo through the action of semen", Charlton, "The Place of Mind in Nature", 415).
} 
The term used for outside, thurathen, is employed elsewhere in the psychological and biological works for external objects - external food (GA 2.4.740b4-5, PA 2.16.659a18, 4.4, 678a6), air that is breathed in by the animal (Somn. 2.456a17, GA 2.6.744a3, PA $1.1 .642 \mathrm{~b} 2,2.16 .659 \mathrm{~b} 18,3.6 .668 \mathrm{~b} 35,4.10 .686 \mathrm{a} 4)^{31}$ and eggs that are lain externally (GA 3.3.754b9).

There is another use of thurathen, however, which allows for a different way to understand the relationship between nous and externality. Thurathen is sometimes used to specify objects which affect an animal from outside of it without being imbibed. In the pseudo-Aristotelian Problemata, for example, the term indicates powers like heat and cold (Aristotle, Problemata 5.9.881b15). These powers are able to alter the body of an animal without having entered it. Thus, if a person were to jump into a cold river, their body would become cold, even if they did not ingest or absorb any of that water internally. In the case of perceptible objects, the external objects again bring about an internal change without actually entering the animal (GA 5.1.780a12, a29; 780b24, On Dreams 2.460b2, b29). This is a form of change Aristotle terms alteration (alloiosis) - an external potential affects an internal capacity and a change occurs - the animal cools down or perceives (De Anima 2.5.416b33-35).

The case of perception is useful for understanding how an animal eventually thinks, activating nous. The power to produce the sensation of red exists externally; under the right conditions, when conjoined with the internal potential to perceive the object of that particular sense; this results in the actualisation of the sense organ and a qualitative change (internally). The animal perceives. The same conceptual pattern is applied by Aristotle to intellection (at least at the first stage; DA 3.4.429a13-18). The objects that can be known are, in some sense, outside the individual knower - and potentially knowable.

One way to explain the comment about "from outside", then, is that this relates to the fact that the intellectual capacity does not begin to develop until a human being exists externally, separated from the parent. Once a person is sensing and moving around, and the structures of their senses, the consistency of their flesh and blood and their spatial orientation are realised, they can become intelligent. Unlike the nutritive and sentient

\footnotetext{
${ }^{31}$ Also some animals, according to Aristotle, take in water to cool themselves (On Respiration 3.471b5).
} 
capacities, nous requires externality in order to begin its activation. ${ }^{32}$ Once reasoning gets going (a while after the child is born, nourished and tutored appropriately ${ }^{33}$ ), then separation of this process from bodily action is possible - there is nothing in the body that operates to make reasoning occur but rather it happens due to the relation that the thinking animal has to the truths that exist.

Some, like Aquinas, cite Aristotle in support of the human soul entering the body at the point at which it has a human shape. Although this rightly acknowledges the importance of the human body as a basis for the ability to think, it fails to accurately locate the moment this 'potentiality' happens. Given that thinking won't be actualised until some time in adolescence, why should the presence of a human shape be much more significant than the presence of a human heart, which is there from the outset? Aristotle does say that it is during development that an animal becomes its proper self -i.e. horse or human (GA 2.3.736b2-5). However, he does not indicate that this need be tied to the development of an external shape. ${ }^{34}$ An embryo that has a heart but no discernible shape is no more or less able to think than one that looks human on the outside. As with other soul capacities, when a human male and female succeed in ensuring the further development of a foetus by bringing together their active and passive potentials to generative another like in kind, the new living being is potentially human. This living being may only have active nutritive functions at the outset, but by the specific manner in which these operate, the sense organs and body type conducive to eventual thinking are being developed and so intelligence is present potentially at this time. ${ }^{35}$

\footnotetext{
${ }^{32}$ Nutritive soul is clearly there from conception onwards (GA 2.3.736a32-36b2). The sentient soul is also present. Although it cannot be fully activated until it meets with all the relevant external sense objects, some sensing will begin while the animal is still in the uterus. One external sensory organ, flesh, develops early on and will respond to the surroundings of the womb or egg experiencing, for example, warmth. Later on, certain animals are discerned to "wake up" in the egg (GA 5.1.779a9, HA 6.3.561b27), indicating a further development of actual sensation.

${ }^{33}$ M. F. Burnyeat, "De Anima II 5", Phronesis 47 (2002): 28-90 at 70n11. “[Mind's] entering from without is as straightforward as our being taught by others" (R. Polansky, Aristotle's De Anima, Cambridge: Cambridge University Press, 2007, 468n.18).

${ }^{34}$ Indeed, Aristotle resists Democritus' emphasis on the importance of external shape in embryology (GA 2.4.740a13-19).

${ }^{35}$ See Charlton "The Place of Mind in Nature", 414, who writes "nous of some kind ought to belong to embryos", and also Michael of Ephesus' position as described in J. Wilberding, Forms, Souls, and Embryos: Neoplatonists on Human Reproduction (London: Routledge, 2017), 114. This point of view is also supported by E. Berti, "Quando Esiste l'Uomo in Potenza? La Tesi di Aristotele", in Nascita e Morte dell'Uomo: Problemi Filosofici e Scientifici, ed. S. Biolo (Genoa: Marietti, 1993), 115-23.
} 
For Aristotle, once understanding is gained and this knowledge can be activated at will, the second actuality of intellect is separable (from our bodies), immaterial and immortal in the Aristotelian sense of our human intellect's participating in divine thoughts. ${ }^{36}$ As unusual as this account of thinking might be, it cannot warrant the "bizarre" conclusion that nous is an external entity imported into an embryo's body. ${ }^{37}$ One reason for this is embryological, the other metaphysical. Embryologically, nous must be there potentially from the moment the embryo is conceived as a human embryo (as just explained). Metaphysically, for Aristotle, something that is immaterial cannot travel through space in the same way that a bodily entity does. ${ }^{38}$ What can be known, eternal truth, is not, strictly speaking, spatially locatable. This intelligibility could be seen as "outside" in a metaphorical sense, which could mean it is never really "inside" either. ${ }^{39}$ Bodies primarily have a place or location, while properties, such as thinking, may be related to them and have a place only in a derivative sense (Ph. 4.2).

Thus we can say that when Abdul thinks of what an elephant is, elephant thinking is happening in the location of Abdul's person. Aristotle famously held that a body cannot be in two different places at the same time. But thinking can be at two places at the same time in this looser sense, as when both Zora and Abdul are thinking of the essence of elephant at the same time. ${ }^{40}$ Thinking does not come into Zora nor Abdul's bodies from outside, like nourishment or breath. And since it seems that thinking can be in a location only in this loose sense, it is not the sort of thing that has to travel through space to get to where it is; thus the question of where intellect comes from is not one that ought to have worried Aristotle. ${ }^{41}$ This makes it even more curious that he talks of nous as entering

\footnotetext{
${ }^{36}$ Second actualisation of intellect is up to us, whereas for the second actualisation of perception to occur, the perceptible object must be there to perceive (DA 2.5.417b20-26).

${ }^{37}$ The description "bizarre" is from Caston, "Aristotle's Two Intellects", 215.

${ }^{38} \mathrm{My}$ account of place and location in Aristotle is based on B. Morrison, On Location: Aristotle's Concept of Place (Oxford: Clarendon, 2002), Introduction.

${ }^{39}$ This is, I take it, the same metaphorical sense that Alexander understands knowledge to be from "above".

40 "Knowledge in individual or humankind, as unchangeable and not dependent upon embodiment, can lose any link with soul and body. It then is just what it is, and because unconnected with any mortal thing, immortal and eternal $\langle\ldots\rangle$ if the intelligible objects are eternal, and knowledge is the same as its object, knowledge should also be eternal. Such mind enters into humans for their brief lives $<\ldots$.. $"$ " (Polansky, Aristotle's De Anima, 466).

${ }^{41}$ P. Moraux, "A Propos de voṽ $\theta u ́ \rho \alpha \theta \varepsilon v$ chez Aristote," in Autour D'Aristote, ed. A. Mansion (Louvain: Publications Universitaires de Louvain, 1955), 255-95 at 286: "l'aporie en question n'est pas nécessairement une aporie qui arrêtait le Stagirite lui-même."
} 
"from outside", indicating a directionality. ${ }^{42}$ This must be explained, then, by the polemic context in which this statement occurs in On the Generation of Animals.

Why is Aristotle concerned with the question of external nous?

The idea that nous enters "from outside" actually does not seem to be Aristotle's own position but that of various opponents he disagrees with. ${ }^{43}$ For example, Aristotle explicitly attributes an "external mind" (ho thurathen nous; Resp. 4.422a23) theory to Democritus. According to Aristotle, Democritus thought of the soul as the mind which is composed of numerous spherical atoms - these are kept in the body by the surrounding air, and are the cause of respiration (DA 1.2.404a1-16). Death occurs when these atoms physically exit the body (Resp. 4.472a14-16). Although he does not say so, it must be that life begins when they enter the body from outside. ${ }^{44}$ We find a similar view in the Hippocratic corpus:

The human soul... which possesses a blend of fire and water, and the parts of a human, enters into every animal that breathes, and in particularly into every human. ${ }^{45}$

Besides materialists, there are those who look for an immaterial substantial soul entering into the embryo, such as Plato and the Orphics. ${ }^{46}$ Aristotle fundamentally disagrees with both materialists and immaterialists. First of all, soul is not to be identified with mind. In those sublunary living beings that have intelligence, all the soul parts are

\footnotetext{
${ }^{42}$ I thank Ben Morrison for pointing this out to me.

${ }^{43}$ See discussion of the dialectic context in Moraux, "A Propos de voũ $\theta u ́ \rho \alpha \theta \varepsilon v$ chez Aristote", 283-7.

${ }^{44}$ Aristotle knows of many theories in which an external soul enters from outside to animate the embryo, such as Diogenes of Apollonia (frags. 7 and 8) and Diocles. See Quarantotto, "Perishable and Imperishable Lives: Aristotle's Analogy with the Heavenly Element in GA II 3.736b29$737 \mathrm{a} 5$ " for further references.

${ }^{45}$ Hippocrates, De Victu 1.25. E. Littré, Oeuvres Complète d'Hippocrate, 10 vols. (Paris, 183961), 6.496.21. For an excellent discussion of this passage see H. Bartos, Philosophy and Dietetics in the Hippocratic On Regimen: A Delicate Balance of Health (Leiden: Brill, 2016), 207-17.

${ }^{46}$ At Phaedrus 249b, a human soul is said to "enter" ( $\left.\varepsilon^{2} v \theta \alpha\right)$ an animal's body and to be able to move from one body to another. "The theory of the so-called poems of Orpheus presents the same difficulty; for this theory alleges that the soul, borne by the winds, enters from the universe into animals when they breathe" (DA 1.5.410b27-411a1).
} 
unified; the soul is not only rational but also nutritive and sentient. ${ }^{47}$ And he disagrees with both groups that this mind/soul enters from outside to animate the embryo. ${ }^{48}$ It is these opponents he addresses when grabbling with the puzzles (a) and (e) from GA 2.13.

Let's return, then, to think about the question of souls entering from outside which occupies Aristotle in puzzle (aporia) (a) (GA 1.1.733b23-734a2). Aristotle asks does the semen transfer something that becomes internal to the new animal - either soul, part of soul, or something that has soul? None of these can be contained in the semen. Male semen cannot even exist as potentially ensouled, because the male contributes no material to the new animal. ${ }^{49}$ Instead, the form of the father (his soul or nature) uses male semen as an instrument to establish another form of the same sort in the embryo. Something that is already $\mathrm{X}$ (the male parent) is making something else $\mathrm{X}$ (GA 2.1.734a30-31; 734b21$3,735 \mathrm{a} 21) .50$

In his own view, the question of "where [the soul] comes from" ( $\pi$ ó $\theta \varepsilon v$ 736a3132 ) is wrongly answered in a physical or spatial way. Soul cannot float in from outside; it is there in the generative products once the correct conditions for conception are achieved. The male contributes a source of substantial change, i.e. the efficient cause. It does not carry in it soul or nous and does not hand over soul capacities. ${ }^{51}$ Aristotle largely solves puzzle (a), then, through his theory of external agency and potentiality. At this point in the treatise, it seems that he is still engaging with an audience who expect to hear something about how soul is transmitted. And in GA 2.3 the questions of where soul comes from re-emerges for the unique status of the intellectual capacity of soul (nous).

It is clear that [similarly to nutritive soul] what we ought to say about sentient and thinking soul. For [the embryo] must possess all [soul capacities] potentially before in actuality. It is necessary that either none exist before they all come to be or that all are present from the outset, or some exist and some do not. And they come to exist either in the matter not entering in with the male

\footnotetext{
${ }^{47}$ As Miller puts it, "rational soul is not a top layer of soul that can be peeled off" (Miller: "Aristotle on the Separability of Mind", 314-5). See endnote 50.

${ }^{48}$ Aristotle also has other reasons for disagreeing for both groups. For example, he complains that materialists cannot properly explain how an animal moves due to something like an act of willthe animal is not simply pushed around by particles or elements (DA 1.3.406b22-26).

${ }^{49}$ See endnote 68.

${ }^{50}$ Cf. Metaph. 7.7.1032a $25 ; 7.8 .1034 \mathrm{a} 35-\mathrm{b} 8$. The answer of how soul gets from father to offspring is partly explained through the use of the automatic puppet comparison (GA 2.1.734b4-17; GA 2.5.741b7-9).

${ }^{51}$ Connell, Aristotle on Female Animals, ch.5.
} 
semen, or having entered then, either all of them having come to be 'from outside' or none or some have and some haven't. ${ }^{52}$

If Aristotle doesn't think that there is any difficulty with nous being there potentially along with the other parts of soul, why does he continually allude to the idea of it possibly entering from outside, and then, in Passage (A) concede that it alone (monon) of all the soul capacities is left to do so? The dense set of possibilities he presents in this passage and puzzle (a) are not in line with his own solution. Why, then, would he set these out in this way? It must be that there are certain theorists he has in mind who present these possibilities in their theories - and he means to address himself to these thinkers. ${ }^{53}$

Aristotle's answer to the external entry hypothesis is that this could only ever work for the thinking part; all other parts of soul must emerge from the embryo itself because they directly involve actions of the body. A good refutation of the entire opposing view can be constructed; it only lacks some final moves.

\section{Main argument:}

If soul enters from outside the embryo, it cannot be present there already.

There are three main capacities of soul: nutritive, sentient and rational.

Nutritive and sentient soul cannot come from outside.

Sub-argument:

Nutritive and sentient soul are dependent on the direct operation or actualisations of parts of the body - e.g. heart, sense organs.

What is dependent on the direct operations/actualisation of parts of the body cannot be separated from the body; what cannot be separated from the body must be present in that body from the outset of development.

Therefore, nutritive and sentient soul are present from the outset and cannot enter from outside at some point later on.

Only the intellectual capacity of soul is not directly dependent on the actualisation of any body part.

Conclusions:

Only the intellectual soul is separable from the body in this sense.

Only the intellectual capacity could (in principle) enter from outside.

Suppressed conclusion:

Intellect cannot be separated from the other soul capacities since soul is a unity, therefore it cannot enter from outside either.

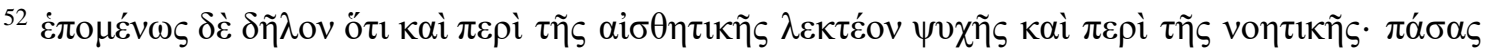

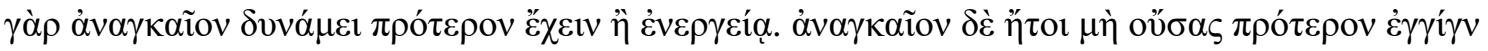

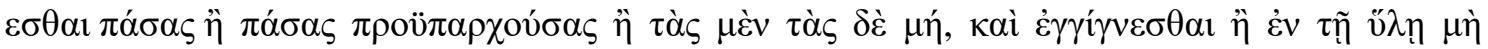

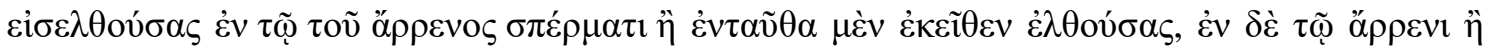

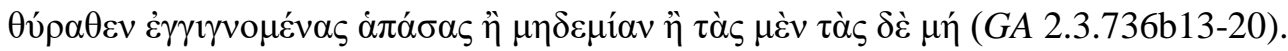

${ }^{53}$ A reading along these lines was suggested to me by both Justin Winzenrieth and David Lefebvre.
} 
This reconstruction leaves us with several questions. First of all, if these thoughts lie behind Aristotle's comment "nous alone [could in principle] enter from outside being divine", why did he not complete the argument against those who said that soul entered from outside the embryo? Another problem is that the opponents are not likely to accept the premises of this argument. For example, the idea that rationality cannot be separated out from the other soul capacities is something that Plato would deny. Furthermore, in one sense, Aristotle himself is also seeking to allow for some type the transcendence for nous, which is presumably why this question keeps returning, occurring numerous times in the De Anima, in On the Parts of Animals and several times in this section of On the Generation of Animals. ${ }^{54}$ One might speculate about the shortcomings of his attempt to challenge the external entry view as follows. Given that On the Generation of Animals is a treatise in the realm of the study of nature, it ought not to involve close analysis of matters that extend far beyond that subject matter.

Although there is some point to the questions raised about the separability of nous, in that the treatise wishes to cover generation in human beings, and human beings are eventually able to think, any detailed analysis of such issues must be reserved for works on first philosophy (i.e. theology, Metaphysics 12) and ethics (i.e. how to lead the most godlike life, EN 10). These discussions, and those in De Anima Book 3, concern a broader category of life, including superlunary and immortal living beings. ${ }^{55}$ Given the focus in this work on generation in all sublunary living beings, questions of anthropological concern do not take precedence. And this may be why Aristotle leaves an unfinished account, being unwilling to enter into debates about nous that are not, strictly speaking, part of the study of nature (PA 1.1.641a33-641b8).

III - Mistaken views of Aristotelian embryology

Throughout Antiquity human generation in particular would continue to perplex a variety of intellectuals. Added to the scientific difficulties were pressing theological questions. Many later religious writers, favouring a dualism that allows for life after

54 Aristotle, DA 1.1.403a9-10; 1.5.411b18-19; 2.1.413a6-7; PA 1.1.641a33-641b10; GA 2.3.736b5-6; 13-29.

55 For more about the differences between De Anima and Aristotle's biological research programme see J. G. Lennox, Aristotle on Inquiry: Erotetic Frameworks and Domain Specific Norms (Cambridge: Cambridge University Press, 2021), ch. 7 "Soul". 
death, sought a point at which soul enters the body by divine intervention. This position generally also requires rejection of hylozoism or animism, whereby materials give rise to life. ${ }^{56}$ Although psychic pre-existence and transmigration of soul must be resisted, this viewpoint fit best to that of Plato who rejects the materialism of his predecessors. What, then, does Aristotle have to contribute?

Those seeking insights about the advent of soul in embryology were aware that Aristotle's views must be considered; after all, he had produced the most comprehensive work on animal generation in classical Antiquity, On the Generation of Animals. While the treatise as whole seems to have gone out of favour after the time of Galen, several passage from it are cited again and again throughout early to late Antiquity and beyond. These include the most famous passage from the whole work, noted above as (A) as well as (B) and (C).

There are four main misrepresentations of Aristotle's position on soul in embryology based on these passages. ${ }^{57}$

(1) Substance immaterialism: Aristotle thinks that mind/soul is an immaterial substance that enters the body of the embryo.

(2) Material carrier thesis: Aristotle thinks that mind/soul is carried in a material to the embryo.

(3) Materialism: Aristotle thinks that mind/soul is a special material.

(4) Creative intellect thesis: Aristotle thinks that mind/soul moulds the embryo.

Substance immaterialism is taken from Passage (A); here intellect (nous) is thought of as the human soul. Passage (A) does indicate some sort of dualism between body and intellect but it does not say when and where nous enters and does not say what it enters. Thus, (1) is not necessary and is, in fact, unsupported by the rest of the Aristotelian corpus. ${ }^{58}$ The material carrier thesis (2) is most often held together with (1) and is based on Passage (B), the idea being that there must be a special material which can carry nous into the body of the embryo, the material that makes up (some part of) male semen,

\footnotetext{
${ }^{56}$ The issue of timing would become central to debates about abortion, which I will not discuss in this paper - see e.g. D. A. Jones, The Soul of the Embryo. An Enquiry into the Status of the Human Embryo in the Christian Tradition (London: Continuum, 2004), Ch. 5.

${ }^{57}$ I will not discuss a further mention of "external mind" at $G A$ 2.6.744b21-23. Moraux's speculation of scribal error is persuasive (Moraux, "A Propos de voṽ $€$ $\theta \dot{\rho} \alpha \theta \varepsilon v$ chez Aristote", 294-5.

${ }^{58}$ Charlton, "The Place of Mind in Nature," 413: "I find it extremely hard to believe that Aristotle in GA II.3 is saying that intellect, in the sense of a capacity for intellectual thought, is transmitted at conception. Nothing of the sort is suggested anywhere else in his work".
} 
usually pneuma. ${ }^{59}$ Since (1) is not secure, (2) is also on shaky ground; if there is no entry of nous into the embryo, then there is no need to find something to take it there. Added to that problem for (2) is the worry that since nous is immaterial, it is very difficult to see why it has to be carried around. (3) Materialism is sometimes discerned from Passage (B) in the thought that soul is literally the element of the stars carried in male semen. This is a position Aristotle opposes; soul cannot be made of any material, but is the actualisation of a living body. ${ }^{60}$ (4) The Creative intellect thesis, which stems from Neoplatonic influences, is unAristotelian through and through. For Aristotle, although soul does mould the embryo; generation is not an intellectual act but a nutritive one.

These misrepresentations come about by interpreting Passage (A)-(C) out of context and without the broader background of Aristotle embryology. ${ }^{61}$ In terms of psychological context, the focus tends to fall on only one portion of the De Anima, Book 3 chapters 4-5 which considers 'intellect' (nous). Here Aristotle distinguishes "productive" from "passive" intellect, and says that the former is "unmixed" and "distinct".

And there is an intellect which is of this kind by becoming all things, and there is another which

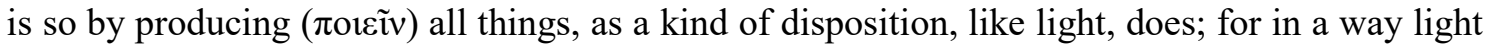
too makes colours which are potential into actual colours. And this [productive] intellect is distinct, unaffected, and unmixed, being in essence activity. ${ }^{62}$

Productive nous can exist separately. "In separation it is just what it is, and this alone is immortal and eternal". ${ }^{63}$ Here we find Aristotle holding the (somewhat confusingly

59 The most comprehensive modern interpretation along these lines is that of A. P. Bos. See A. P.
Bos, "Pneuma and Ethics in Aristotle's Philosophy of Living Nature", The Modern Schoolman
79 (2002): 255-76; A. P. Bos, The Soul and Its Instrumental Body: A Reinterpretation of
Aristotle's Philosophy of Living Nature (Leiden: Brill, 2003); A. P. Bos "The 'Vehicle of Soul'
and the Debate Over the Origin of this Concept" Philologus 151 (2007): 31-50; Bos, Aristotle on
God's Life-Generating Power. See Connell, Aristotle on Female Animals, Ch. 6.2 for references
to other advocates of this position (including Balme, as detailed in section II above).

${ }^{60}$ Aristotle, De Anima 2.2.414a27-29.

${ }^{61}$ On the importance of the context, see also Moraux, "A Propos de voṽ $\theta v ́ \rho \alpha \theta \varepsilon v$ chez Aristote".

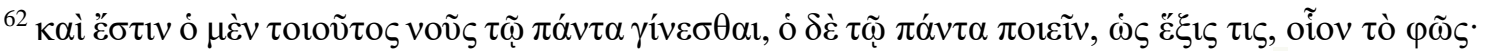

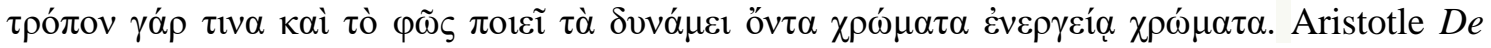
Anima (DA) 3.5.430a14-17. Translation from: Aristotle, De Anima Books II and III (with passages from Book I), translated with introduction and notes by D. W. Hamlyn (Oxford: Clarendon, 1993): 60. There is no room here to set out the many controversies about productive intellect. For a good overview see especially Aristotle: De Anima, translated with introduction and commentary by C. Shields (Oxford: Clarendon, 2016): 312-17 and Miller, "Aristotle on the Separability of Mind".

${ }^{63}$ Aristotle $D A$ 3.5.430a24-5. 
expressed) view that intellectual capacity (nous) is separable from the body. On certain convincing interpretations of this section of text, it means that when people think about truths, they transcend matter in a special sense. This does not mean, however, that Aristotle thinks minds can literally float free from bodies and travel out of or into them. Furthermore, the materials needed for animal generation do not literally carry soul, as Aristotle is keen to point out in the section of On the Generation of Animals (see section III). For Aristotle, soul is neither a separate substance nor made of a material. It is a nonmaterial actualisation, a property or aspect of the body which cannot exist independently in a substantial sense.

While the passages themselves tended to take commentators far beyond what Aristotle would countenance, some understood the importance of the body to Aristotle's psychology and were more circumspect about how far his philosophy could be accommodated to survival of the soul after death. Amongst those who appreciated the key differences between Plato and Aristotle were early Christian thinkers, such as Gregory of Nyssa, Numesius and Tertullian. ${ }^{64}$ In these writing we have a window into a world that is not as dominated by the synthesising ambitions of later thinkers. Most early Christian thinkers acknowledge Aristotle's views on the intertwinement of soul and body, which although it must be resisted in part in order to secure personal immortality, could also be useful in illuminating the importance of an embodied humanity.

\section{The history of an idea}

The role these popular passages have played in the history of Western thought is hugely complicated. The following provides only a very general account of some key debates and developments. The main concern is to highlight the above misrepresentations and how they were aided by taking the Passages (A)-(C) out of context and using them to support unAristotelian positions.

After the turning away from natural science in Aristotle's school, the Hellenistic period saw a lack of philosophical engagement with his biological works and produced

${ }^{64}$ Their more accurate analysis may have been partly due to a better access to Aristotle's biological treatises. Clement even quotes fragments of works no longer extant. See G. Karamanolis, "Early Christian Philosophers on Aristotle", in Brill's Companion to the Reception of Aristotle in Antiquity, ed. A. Falcon (Leiden: Brill, 2016): 460-79 at 460-2. 
very little in the way of commentary on embryology. ${ }^{65}$ A single hint in the second century grammarian Aristophanes of Byzantium, suggests that Passage (A) had inspired the idea that intellectual soul played some part in embryology, but the term used for it, "noeron", is distinctly "unAristotelian". ${ }^{66}$ By the time of the more serious engagement of Alexander of Aphrodisias and the medico-philosopher, Galen, in the $2^{\text {nd }}$ century C. E., Aristotle's biological works were marginalised and absent from the curriculum. ${ }^{67}$

Along with many other interpretations, Alexander relates Passage (A) to De Anima 3.4-5 on intellect (nous). ${ }^{68}$ Despite not engaging directly with biological topics in Aristotle, Alexander's view is sensitive to Aristotelian naturalism. Alexander notices the difficulty of immaterial, immortal intellect, as described in De Anima 3.5. If this is what is being referred to as 'divine' in the $G A$ passage, why would it need to have a location? ${ }^{69}$ He solves this by positing that because intellectual activity is not the actualisation of any body, there must be a correct blend that can "receive" intellect, a body that is capable of thinking, the instrument of intellect. But intellect is present even when its instruments are not in use, just as carpentry is there even when the carpenter is not using his tools. As Falcon puts it, for Alexander, "the intellect comes from outside in the sense that it is not a capacity of our soul but it has to be present in us when we think... When we think we partake of its incorruptibility". ${ }^{70}$ What Alexander's view does not explain, presumably because he is not reading this as part of embryology, is how it is that the body can develop to become the sort of body that will be able to think.

${ }^{65}$ J. G. Lennox, "The Disappearance of Aristotle's Biology: A Hellenistic Mystery", in The Sciences in Greco-Roman Society, ed. T. D. Barnes (Edmonton: Academic Printing and Publishing, 1995): 7-24.

${ }^{66}$ See M. Hatzimichali, "The Early Reception of Aristotle's Biology", in The Cambridge Companion to Aristotle's Biology, ed. S. M. Connell (Cambridge: Cambridge University Press, 2021): 228-245.

${ }^{67}$ A. Falcon, "The Reception of Aristotle's Biology in Late Antiquity and Beyond", in The Cambridge Companion to Aristotle's Biology, ed. S. M. Connell (Cambridge: Cambridge University Press, 2021): 246-260; Wilberding, Forms, Souls, and Embryos, 2-3.

${ }^{68}$ The relationship between Aristotle's concept of productive intellect and the human soul occupied thinkers from the time of Theophrastus onwards. Falcon, "The Reception of Aristotle's Biology in Late Antiquity and Beyond," endnote 15.

${ }^{69}$ Mantissa 2.2.5-II 3.6; Alexander of Aphrodisias. "De Anima Libri Mantissa" in Alexandri Aphrodisiensis Praeter Commentaria Scripta Minora, ed. I. Bruns. Commentaria in Aristotelem Graeca Suppl. 2.1 (Berlin: Reimer, 1887): 101-186. This is nicely explained by R.W. Sharples, Peripatetic Philosophy, 200 BC to AD 200: An Introduction and Collection of Sources in Translation (Cambridge: Cambridge University Press, 2010): 272.

${ }^{70}$ Falcon, “The Reception of Aristotle's Biology in Late Antiquity and Beyond". 
Contemporaneous with Alexander was Claudius Galen, probably the thinker who knew Aristotelian embryology better than anyone else until the later Middle Ages. He sets up his own theory of generation in opposition to that of Aristotle. ${ }^{71}$ In this polemical state of mind, Galen struggles to understand the GA 2.3 passages. Reading $\sigma \pi \varepsilon \dot{\varepsilon} \rho \mu \alpha$ (semen) instead of $\sigma \tilde{\omega} \mu \alpha$ (body/bulk) in Passage (B) adds to the confusion.

[Aristotle] writes as follows: 'the body of the semen-in which the seed also travels from its origin in soul, being in part separable from body, [the part] in which the divine is contained (and like

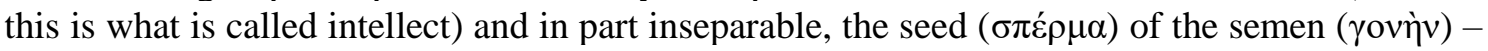
is dissolved and turned to pneuma, having a moist and watery nature'. ${ }^{72}$

The thought seems to be that there is a physical part of semen (the 'seed') which evaporates and a non-physical part which is intellect. This then leads to more far-fetched interpretations, suggesting the (4) Creative intellect thesis. ${ }^{73}$ Galen appears to have a (2) Material carrier thesis at this point. Another reference to Passage (B) sees Galen come close to (3) Materialism.

And if we must speak of the substance of the soul, we must say one of two things: we must say either that it is this, as it were, bright and etherial body, a view to which the Stoics and Aristotle are carried in spite of themselves, as the logical consequence (of their teachings), or that it is (itself) an incorporeal substance and this body is its first vehicle, by means of which it establishes partnership with other bodies. ${ }^{74}$

\footnotetext{
${ }^{71}$ Although this opposition has been exaggerated. See especially S. M. Connell, "Aristotle and Galen on Sex Difference and Reproduction: A New Approach to an Ancient Rivalry," Studies in the History and Philosophy of Science, 31/3 (2000): 405-427 and R. Flemming, "Galen's Generations of Seeds", in Reproduction: Antiquity to The Present Day, eds. N. Hopwood, R. Flemming and L. Kassell (Cambridge: Cambridge University Press, 2018): 95-108.

${ }^{72}$ Galen, Sem. 1.3. Galeni De Semine. ed. P. De Lacy. Corpus Medicorum Graecorum V 3,1 (Berlin: Akademie Verlag, 1992), 69-70. Translation from Sharples, Peripatetic Philosophy: 253.

${ }^{73}$ For an early example of this mistaken view see Pseudo-Plutarch, Summary of the Opinions of the Philosophers Concerning Nature 5.4 905B. Aetius, De Placita Philosophorum 5.4.2, in H. Diels Doxographi Graeci Collegit Recensuit Prolegomenis Indicibusque Instruxit (Berlin: De Gruyter, 1879), 417a215. For Aristotle, nature works to form a new animal via the nutritive soul which does not have any intellectual content or intention. On this, see Connell, Aristotle on Female Animals, ch. 6.2.

${ }^{74}$ Galen PHP 7.7.25. De Lacy 474,22-27 = K. 5.643. Galen. Galeni De Placitis Hippocratis et Platonis. ed. P. De Lacy. Corpus Medicorum Graecorum V 4,1,2 (Berlin: Akademie Verlag, 1978-1984), 474.22-27. Translation from P. N. Singer, "Galen on Pneuma: Between Metaphysical Speculation and Anatomical Theory", in Pneuma After Aristotle, eds. S. Coughlin, D. Leith and O. Lewis (Berlin: Edition Topoi, 2020), 237-82 at 269. See also C. W. Wolfe, "Galen's Contribution to the History of Materialism", in Galen and the Early Moderns, eds. M. F. Camposampiero and E. Scribano, eds., (Springer, 'Archives Internationales d'Histoire des Idées', 2021).
} 
From this passage, Galen seems to think that Aristotle ascribed to a materialistic view very like that of the Stoics, who held that soul was pneuma in tension. ${ }^{75}$

After Galen, interpretations of Aristotle's views on intellect come into the project of synthesizing his philosophy with that of Plato. Without the biological and zoological works in circulation, the task is easier. Perhaps unsurprisingly, this one set of passages from the $G A$ becomes even more important. While Plato did not engage in empirical natural philosophy, he can be said to have had views on embryology, views that were to be developed into a Neoplatonic position in later Antiquity. ${ }^{76}$ Our clearest text for this is Porphyry's Ad Gaurum which understands the intellect coming "from outside" as a type of emanation of the soul from a divine source. This is one of the most significant developments in (1) Substance Immaterialist. For Porphyry, the immateriality of the soul is key, disagreeing on this point with his Stoic opponents. ${ }^{77}$ Probably the most influential proponent of this view was the Christian Neoplatonist Philoponus who also develops the (2) Material carrier thesis. "Overinterpreting" Aristotle in a Platonic manner, Philoponus focuses on nous coming "from outside" and describes this as the descent of intellectual soul which becomes embodied through the "pneumatic body" ${ }^{78}$

Passage (A) would come to generally to support (1) Substance immaterialism and Passage (B), the (2) Material carrier thesis. ${ }^{79}$ A new debate emerges from this view about when and by what power intellect enters the embryo. Aristotle says it comes "from outside" and "is divine", so it would seem logical to conclude that the immaterial substantial soul comes from God, who implants it in the embryo (a view that would come

\footnotetext{
${ }^{75}$ For an interesting discussion of Galen's possible reading of Aristotle's $G A$ along these lines, see Singer, "Galen on Pneuma".

${ }^{76}$ For the fullest account of Platonic and Neoplatonic embryology see Wilberding, Forms, Souls, and Embryos.

${ }^{77}$ Wilberding, Forms, Souls, and Embryos: 133, 136; M.-H. Congourdeau, "Debating the Soul in Late Antiquity", in Reproduction: Antiquity to The Present Day, eds. N. Hopwood, R. Flemming and L. Kassell (Cambridge: Cambridge University Press, 2018): 109-122 at 116.

${ }^{78}$ From M.-H. Congourdeau, "L'embryon Entre Néoplatonisme et Christianisme", in OriensOccidens: Sciences, Mathématiques et Philosophie de l'Antiquité à l'Age Classique (Paris: Université Paris 7 - Denis Diderot, 2002), 201-16. For this position, see also the description of Wilberding, Forms, Soul, and Embryos, 136: "The pneumatic body theory holds that the individual rational soul, as it descends from the intelligible region through the celestial spheres, acquires a pneumatic body and with it the non-rational soul en route".

${ }^{79}$ For Platonist sympathizers, one can see the attraction of this position as it seems to be in line with Timaeus 41e where souls are said to first enter the human body after God had earlier placed them in a star, as in a chariot.
} 
to be known as "creationism"). The alternative view was that due to sin originating in Adam, the soul must be given in the seed of the father (so-called "traducianism"); one prominent advocate of the latter position was Augustine. ${ }^{80}$

For (1) Substance immaterialism, the question of when God or dad implants intellectual/human soul remains. While Porphyry is insistent that ensoulment happens at birth, which was also the view of Stoic materialists, later thinkers chose either at conception or at some point during gestation. Aristotle is sometimes understood to think that nutritive and sentient soul come with the male semen, while intellectual soul comes from outside the embryo at the point when the embryo has a human shape; this is a view first developed by Jerome in the $4^{\text {th }}$ century and can be found most famously in Aquinas. ${ }^{81}$ Advocates focus on a passage from the Historia Animalium which says that male embryos are formed at 40 days, females at 90 days. ${ }^{82}$ Despite the rare reference to a genuine zoological text, the position is not Aristotelian, since he never indicates that full formation is required in order for human soul to be present in the embryo. ${ }^{83}$

Our ideas of these texts are also shaped by later Medieval interpretations. Rather than extract only certain portions of the biological works, philosophers in the Arab tradition studied and knew the content of the entire works. ${ }^{84}$ These thinkers also grappled with previous traditions of interpretation. When understanding the $G A$ passages above, troubled translations by Ibn Bajja also played a role as well as a certain preoccupation with finding a place for personal immortality. Combined with certain interpretations of the passages from De Anima Book 3, both Avicenna and Averroes viewed the intellectual

\footnotetext{
${ }^{80}$ For more on this controversy see Jones, The Soul of the Embryo, ch. 7.

${ }^{81}$ Congourdeau, "Debating the Soul", 116.

${ }^{82}$ Aristotle, Historia Animalium 7.3.583b14-23. Aristotle is not actually this precise, but rather indicates that [human] male embryos are differentiated by three months' and female ones at about four months' gestation. This view was favoured because it seemed to accord with the first book of Genesis which was read to mean that the soul was breathed in once the body had been moulded. Catenae Graecae in Genesim et in Exodum, ed. F. Petit, vol. 2: Collectio Coisliniana in Genesim (Turnhout: Brepols, 1986): 86-7. Congourdeau, "Debating the Soul”, 114.

${ }^{83}$ For a fuller discussion see K. J. Flannery, "Applying Aristotle in Contemporary Embryology," The Thomist 67 (2003): 249-78.

${ }^{84}$ Avicenna's knowledge of On the Parts of Animal and On the Generation of Animals is very much in evidence. His own generation theory is close to that of Aristotle. B. Musallam, "The Human Embryo in Arabic Scientific and Religious Thought", in The Human Embryo: Aristotle and the Arabic and European Traditions, ed. G. R. Dunstan (Exeter: University of Exeter Press, 1990), 32-46. Averroes wrote a commentary on On the Generation of Animals which survives in a Hebrew translation. Davidson, Alfarabi, Avicenna, and Averroes on the Intellect, 233.
} 
soul as separable as "final cause" of the other soul parts, a view not held by Aristotle. ${ }^{85}$ Avicenna also held that the intellectual soul is created with the body, and following the Neoplatonist scheme "emanated" from the Divine Intellect, and then survives after death. ${ }^{86}$ In embryological terms, the parents prepare a body appropriate for receiving intellect. ${ }^{87}$ For this tradition, then, the expression "from outside" from the Generation of Animals was taken to support the idea of emanation and transplantation of individual human intellectual souls. In the phrase "sometimes separable from matter" in Passage (C), the Arabic drops the "sometimes" so they take it that the "origin of soul" carried by semen is divine, i.e. from God. ${ }^{88}$ Thus we see a combination of (1) Substance immaterialism and the (2) Material carrier thesis, but with a sensitivity to the importance of the human body for eventual intellectual understanding in human life.

In the Latin West, the scholastic position was similar to that of the Arabs. The differences were that there was less nuance about the state of the body and that the issue of timing became more central. For some Latin thinkers, such as Albertus Magnus, who would be the first to translate Aristotle's zoological works into Latin, the (4) Creative intellect thesis is added - the intellect (nous) transmitted by the semen becomes responsible for the construction of the embryo. ${ }^{89}$

In the early modern period, Aristotelian embryology came into focus again. What was at issue initially is a rejection of Aristotelian natural philosophy on the grounds of its inconsistency with Christian doctrine. ${ }^{90}$ One problem cited was the impossibility of the soul's immortality in Aristotle, a rejection, then, of certain readings of Passage (A).

${ }^{85}$ R. Winovsky, "Avicenna and the Avicennian Tradition", in The Cambridge Companion to Arabic Philosophy, ed. P. Adamson (Cambridge: Cambridge University Press, 2005): 92-136, at 101-2.

${ }^{86}$ See especially Wisnovsky "Avicenna and the Avicennian Tradition": 102; D. L. Black, "Psychology: Soul and Intellect", in The Cambridge Companion to Arabic Philosophy, ed. P. Adamson (Cambridge: Cambridge University Press, 2005): 308-326 at 318.

${ }^{87}$ Black, "Psychology: Soul and Intellect": 310.

88 "On Ibn Bajja's reading, souls in the sublunary realm come from an incorporeal substance - an agent that contains in itself the soul of all living beings and imparts them to the sublunar matter" (Davidson Alfarabi, Avicenna, and Averroes on the Intellect, 233).

${ }^{89}$ P. Allen, The Concept of Woman: The Aristotelian Revolution, 750 BC-AD 1250 (Montreal: Eden Press, 1985), 368.

${ }^{90}$ Particularly by Pomponazzi (1462-1525) (Wolfe, "Galen's Contribution to the History of Materialism") and then taken up again much later by Gassendi (1592-1655). See D. Levitin, Ancient Wisdom in the Age of the New Science (Cambridge: Cambridge University Press): 43133. 
Accusations of 'animism' and 'idolatrous animism', i.e. the idea that nature is animate, leaving no place for God, were rife. While Aristotle, partly due to some of the interpretations we have looked at already, was often thought of as less open to this charge than Plato or Epicurus, many thinkers in $16^{\text {th }}$ and $17^{\text {th }}$ century saw Passage (B) as evidence for an animation of the elements, making this a form of (3) Materialism. This idea became so entrenched that by the time of Locke Aristotle's position is, ironically, lumped in with the Cambridge Platonist's view that a "plastic power" or "spirit of nature" is responsible for living beings. ${ }^{91}$

Part of the difficulty with understanding these passages and others on 'intellect' (nous) is that Aristotle holds to neither of the two more straightforward positions of substance dualism and materialism. For Aristotle, the intellectual capacity of human beings is unlike the other two main soul capacities, nutritive and sentient, by being in some sense "separable", "unmixed" and "immortal"; thus, he espouses some sort of dualism but not one that is easy to pin down. ${ }^{92}$ Intellectual activity does not involve the actualisation of any organ of the body ( $D A$ 2.2.413a4-9); it cannot in order to retain its plasticity, since the human mind must be able to understand all the true essences of things. ${ }^{93}$ When, through a long and arduous process, human beings are able to grasp eternal truths and contemplate them, the part of themselves that achieves this becomes one with these objects of knowledge. ${ }^{94}$ Thus, a person, when she is thinking of these truths, becomes like God, pure thought. "To contemplate the essences of things $\langle\ldots\rangle$ is to enjoy the ultimate intellectual attainment. It is quite literally to think God's thoughts". ${ }^{95}$

${ }^{91}$ Those who take Aristotle to be animism in this period include Bacon, van Helmont, Boyle, Glisson and Harvey. For a fascinating account of this particular history of interpretation of Passage (B), especially in England, see Levitin, Ancient Wisdom in the Age of the New Science, 398-432.

${ }^{92}$ In terms of more modern positions, the view is closest to epiphenomenalism or emergentism. See discussion in Connell, Aristotle on Female Animals, ch. 6.3.

${ }^{93}$ Essences are said to be in the mind or soul (Aristotle, De Anima 2.5.417a21-23; 3.4.429a27; Posterior Analytics 2.19.100a5-9; 2.14.98a15-17; Metaphysics 7.15.1040a3-4). On the plasticity requirement see Shields, Aristotle: De Anima: 294 and C. Cohoe, "Why the Intellect Cannot have a Bodily Organ," Phronesis 58/4 (2013): 347-77.

94 "What is called mind of the soul...is none of the beings in actuality before it thinks" (o ö $\rho \alpha$

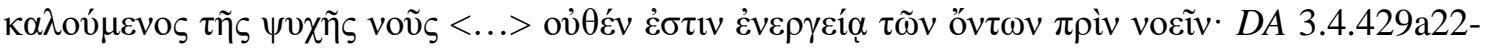
24).

${ }^{95}$ D. Sedley, "The Ideal of Godlikeness," in Plato 2: Ethics, Politics, Religion, and the Soul, ed. G. Fine (Oxford: Oxford University Press, 1999): 309-28 at 328. As Sedley reminds us, Aristotle says that the highest form of happiness is to contemplate such truths and "to the extent one can, 
This position leaves no room either for immaterial substances in humans that are 'minds' or for the survival of individual souls after death. ${ }^{96}$ For human beings, thinking is only sustained via the senses and a human body during this life. This view depends on certain readings of De Anima 2 and 3 that accord with a more naturalistic and biological understanding than some. A major difficulty for this interpretation is precisely the Passage (A) on nous entering "from outside"; there seems little reason why that would need to happen if intellectual activity is the culmination of human development, taking place long after birth. Unless Aristotle thought of intellect as something separable and handed over to a human embryo, in effect, making it fully human, why would he need to mention this in the $G A$ section on the way in which seed is related to soul? Thus does that passage challenges naturalistic Aristotelianism.

\section{IV - Early Christian thinkers on Aristotle's biology}

Early Christian engagement with Aristotle was mainly dismissive. In general, these thinkers appeared to appreciate that his views about soul pulled against many Christian doctrines. This may have been due to a better acquaintance with Aristotle's zoological writings which provides the requisite naturalistic background and thus a better understanding of his position. ${ }^{97}$ With respect to the content of On the Generation of Animals, early Christian commentators were more inclined to regard it with suspicion than to adopt Passages (A)-(C) as part of their own understanding. A good example of this is Eusebius' reflection on the Platonist Atticus' complaints against Aristotle's embryology. Atticus points out that if intellect is incorporeal then it cannot move from one place to another and so cannot "come from outside". 98 This led him to believe that

to immortalize" (Aristotle, Nicomachean Ethics 10.7.1177b33). The passage recalls exhortations that individuals attempt to resemble God in Plato's Timaeus.

${ }^{96}$ It can be argued that Aristotle's God is such a substance. On this see S. Menn, "Aristotle and Plato on God as Nous and as the Good", Review of Metaphysics 45 (1992): 543-73. In us, it is not a substance, but an activity of thinking (Shields, Aristotle: De Anima, 293).

${ }^{97}$ Clement, for example, describes Aristotle as a 'natural scientist' (phusikos) rather than as a philosopher. Karmanolis, "Early Christian Philosophers on Aristotle", 463.

${ }^{98}$ Sharples, Peripatetic Philosophy, 273. 
Aristotle did not allow for the soul's substance immateriality despite Passage (A) ${ }^{99}$ This view was also held by Gregory of Nyssa and Numesius. ${ }^{100}$

While approvingly referencing Aristotle's biological works, Numesius criticises soul as actuality; for him, Aristotle fails to make intellect independent of the body in the required manner. Meanwhile Gregory understood the importance of the embryological development to understanding the interdependency of soul and body. Using an Aristotelian view, he argued that soul was present from conception, even if faculties manifest themselves later on as the body develops. ${ }^{101}$ This view is indeed much closer to what Aristotle himself thought than the one that would become so prominent in later Christian thinkers, that the body had to look human first. Soul is not fully actualised until the foetus emerges and can sense and nourish itself; it is there potentially from the outset as a human soul, with the potential to eventually think.

For Aristotle, the human soul, even in its intellectual capability, is closely tied to the human body. The intertwinement of soul and body meant that there would have to be body ready to receive a newly constructed soul, a view which was also popular with Arab philosophers. The sense in which intellectual capacity is separable has less to do with dualism than it does to Aristotle's way of explaining our understanding of godlike truth. What is impossible to find without distortion is any way for individual human beings to be eternal and immortal. While those who recognised this were gradually pushed aside (e.g. Alexander, Averroes), a close association between Platonic and seemingly Aristotelian theories could be maintained; this would eventually allow a somewhat distorted dualistic Aristotelianism to form part of later Christian theology. However, early Christian engagement with Aristotle reveals a recognition that his views would not fully suit that particular agenda. ${ }^{102}$

Despite the tendency to treat Aristotle with suspicion, early Christian commentators' serious engagement with the content of his biological works would be very important to certain aspects of their thinking. As already mentioned, it allowed a

\footnotetext{
${ }^{99}$ M. Edwards, Aristotle and Early Christian Thought (London: Routledge, 2019), 23.

${ }^{100}$ Numesius, On Nature of Man 27.11-14. Karamanolis, "Early Christian Philosophers on Aristotle", 476.

${ }^{101}$ Gregory of Nyssa On the Making of Man 28; this was also the view of Tertullian. See Congourdeau "Debating the Soul", 112.

${ }^{102}$ Early Christian thinkers were more sympathetic to Plato than Aristotle (Jones, The Soul of the Embryo: 81; Karamanolis "Early Christian Philosophers on Aristotle").
} 
way to resist the possibility of the transmigration of souls or implantation of already existing souls, which early Platonic dualism was built upon. An appreciation for the Aristotelian naturalistic viewpoint also provided potential resources in other areas. For example, knowledge of Aristotle's embryology was to allow for a richer account of the virgin birth. The humanity of Jesus is not something handed over on high but is within the refined materials of a woman's body, which would go to make up his own human body. ${ }^{103}$ And the close connections between human bodies and souls not only explained the joining of a new soul to a human body at the beginning of life, but also the need for bodily resurrection in the life to come.

Sophia Connell

Birkbeck, University of London

\section{References}

Allen, P. (1985) The Concept of Woman: The Aristotelian Revolution, 750 BC-AD 1250, Montreal: Eden Press.

Bartos, H. (2016) Philosophy and Dietetics in the Hippocratic On Regimen: A Delicate Balance of Health, Leiden: Brill.

Berti, E. (1993) "Quando Esiste l'Uomo in Potenza? La Tesi di Aristotele", in Nascita e Morte dell'Uomo: Problemi Filosofici e Scientifici, ed. S. Biolo, Genoa: Marietti: 115-23.

Bos, A. P. (2003) The Soul and Its Instrumental Body: A Reinterpretation of Aristotle's Philosophy of Living Nature, Leiden: Brill.

Bos, A. P. (2007) "The 'Vehicle of Soul' and the Debate Over the Origin of this Concept" Philologus 151: 31-50.

Bos., A. P. (2002) "Pneuma and Ethics in Aristotle's Philosophy of Living Nature", The Modern Schoolman 79: 255-76.

\footnotetext{
${ }^{103}$ For the female contribution as refined materials and menstrual blood as the substance of the human body see Clement Paed. 1.6.48.1-3; 1.6.49-1-2 and commentary in B. Pouderon, "La Conception Virginale chez les Premiers Pères de L'Église. Réflexions sur les Rapports entre Théologie et Physiologie", in Regards sur le Monde Antique. Hommage à Guy Sabbah, ed. M. Poit (Lyon: Presses Universitaires de Lyon, 2002) : 229-255.
} 
Congourdeau, M.-H. (2002) "L'embryon Entre Néoplatonisme et Christianisme", in OriensOccidens: Sciences, Mathématiques et Philosophie de l'Antiquité à l'Age Classique, Paris: Université Paris 7 - Denis Diderot: 201-16.

Congourdeau, M.-H. (2018) "Debating the Soul in Late Antiquity", in Reproduction: Antiquity to The Present Day, eds. N. Hopwood, R. Flemming and L. Kassell, Cambridge: Cambridge University Press: 109-122.

Connell, S. M. (2000) "Aristotle and Galen on Sex Difference and Reproduction: A New Approach to an Ancient Rivalry", Studies in the History and Philosophy of Science, 31/3: 405427.

Edwards, M. (2019) Aristotle and Early Christian Thought, London: Routledge.

Falcon, A. (2021) "The Reception of Aristotle's Biology in Late Antiquity and Beyond", in The Cambridge Companion to Aristotle's Biology, ed. S. M. Connell, Cambridge: Cambridge University Press.

Flemming, R. (2018) “Galen's Generations of Seeds", in Reproduction: Antiquity to The Present Day, eds. N. Hopwood, R. Flemming and L. Kassell, Cambridge: Cambridge University Press: 95-108.

Hatzimichali, M. (2021) "The Early Reception of Aristotle's Biology", in The Cambridge Companion to Aristotle's Biology, ed. S. M. Connell, Cambridge: Cambridge University Press: 228-245.

Jones, D. A. (2004) The Soul of the Embryo. An Enquiry into the Status of the Human Embryo in the Christian Tradition, London: Continuum.

Lennox, J. G. (1995) “The Disappearance of Aristotle's Biology: A Hellenistic Mystery”, in The Sciences in Greco-Roman Society, ed. T. D. Barnes, Edmonton: Academic Printing and Publishing: 7-24.

Lennox, J. G. (2021) Aristotle on Inquiry: Erotetic Frameworks and Domain Specific Norms, Cambridge: Cambridge University Press.

Menn, S. (1992) "Aristotle and Plato on God as Nous and as the Good", Review of Metaphysics 45: 543-73.

Moraux, P. (1995) "A Propos de voṽ $\theta 0 ́ \rho \alpha \theta \varepsilon v$ chez Aristote”, in Autour D’Aristote, ed. A. Mansion, Louvain: Publications Universitaires de Louvain: 255-95.

Morrison, B. (2002) On Location: Aristotle's Concept of Place, Oxford: Clarendon.

Musallam, B. (1990) "The Human Embryo in Arabic Scientific and Religious Thought", in The Human Embryo: Aristotle and the Arabic and European Traditions, ed. G. R. Dunstan, Exeter: University of Exeter Press: 32-46.

Polansky, R. (2007) Aristotle's De Anima, Cambridge: Cambridge University Press.

Singer, P. N. (2020) "Galen on Pneuma: Between Metaphysical Speculation and Anatomical Theory", in Pneuma After Aristotle, eds. S. Coughlin, D. Leith and O. Lewis, Berlin: Edition Topoi: 237-82.

Wilberding, J. (2017) Forms, Souls, and Embryos: Neoplatonists on Human Reproduction, London: Routledge.

Winovsky, R. (2005) “Avicenna and the Avicennian Tradition", in The Cambridge Companion to Arabic Philosophy, ed. P. Adamson, Cambridge: Cambridge University Press: 92-136. 